Northwestern University School of Law Northwestern University School of Law Scholarly Commons

Faculty Working Papers

2010

\title{
Price Setting and Hoarding in Mamluk Egypt
}

Kristen Stilt

Northwestern University School of Law, stilt@law.northwestern.edu

\section{Repository Citation}

Stilt, Kristen, "Price Setting and Hoarding in Mamluk Egypt" (2010). Faculty Working Papers. Paper 45.

http://scholarlycommons.law.northwestern.edu/facultyworkingpapers/45 


\title{
THE LAW APPLIED
}

Contextualizing the Islamic Shari‘a

\section{$\mathbb{C}$}

A Volume in Honor of Frank E. Vogel

\author{
Edited by \\ Peri Bearman \\ Wolfhart Heinrichs \\ Bernard G. Weiss
}

\section{I.B. T A U R I S}


Published in 2008 by I.B.Tauris \& Co Ltd

6 Salem Road, London W2 4BU

175 Fifth Avenue, New York, NY 10010

www.ibtauris.com

In the United States of America and Canada distributed by Palgrave Macmillan

a division of St. Martin's Press, 175 Fifth Avenue, New York, NY 10010

Copyright @ Peri Bearman, Wolfhart Heinrichs, Bernard G. Weiss, 2008

The right of Peri Bearman, Wolfhart Heinrichs, Bernard G. Weiss to be identified as the author of this work has been asserted by the author in accordance with the Copyright, Designs and Patent Act 1988.

All rights reserved. Except for brief quotations in a review, this book, or any part thereof, may not be reproduced, stored in or introduced into a retrieval system, or transmitted, in any form or by any means, electronic, mechanical, photocopying, recording or otherwise, without the prior written permission of the publisher.

ISBN 9781845117368

A full CIP record for this book is available from the British Library

A full CIP record for this book is available from the Library of Congress

Library of Congress Catalog Card Number: available

Printed and bound in Great Britain by TJ International Ltd, Padstow, Cornwall 


\section{GONTENTS}

Preface, by William P. Alford vii

Foreword ix

1. Charles Donahue, Jr., Reform, Renewal, Religion, and Social Discipline: Reflections of a Medievalist

2. John Makdisi, The Kindred Concepts of Seisin and Hawz in English and Islamic Law

3. Louise Halper, "Legal Realism" in Tehran: Gender Law and the Transformative State

4. Kristen Stilt, Price Setting and Hoarding in Mamluk Egypt: The Lessons of Legal Realism for Islamic Legal Studies

5. Rudolph Peters, Sharecropping in the Dakhla Oasis: Shari a and Customary Law in Ottoman Egypt

6. Mark E. Cammack and R. Michael Feener, Foint Marital Property in Indonesian Customary, Islamic, and National Law

7. Muhammad Khalid Masud, A Study of Wakin's (d. 306/917) Akhbār al-Quḍāt

8. Aharon Layish, The Heritage of Ottoman Rule in the Israeli Legal System: The Concept of Umma and Millet

9. Amira El-Azhary Sonbol, Class and Violence in NineteenthCentury Egypt

10. Brinkley Messick, Shari'a Ethnography

11. Chibli Mallat, Constitutions for the Twenty-First Century: Emerging Patterns-The EU, Iraq, Afghanistan...

12. Martin Lau, Legal Reconstruction and Islamic Law in Afghanistan 


\title{
PRICE SETTING AND HOARDING IN MAMLUK EGYPT \\ The Lessons of Legal Realism for Islamic Legal Studies
}

\author{
Kristen Stilt
}

One of the main purposes of Frank Vogel's book, Islamic Law and Legal System: Studies of Saudi Arabia, is "to contribute to the understanding of Islamic law by studying it in the process of its application." This purpose derives from Vogel's assessment that "Our lack of knowledge of the systems by which Islamic law is and has been applied has greatly hindered our understanding of this law." 2 Further, he noted, "Continued ignorance of the law in practice weakens our understanding of Islamic religion, Islamic history, and Muslim societies past and present. But most of all, it undermines our understanding of Islamic legal doctrine and theory."33

Vogel's concerns remain pressing, and his own work serves as needed guidance to scholars of Islamic law today. Many studies that aim to advance the knowledge of Islamic laws or legal systems are formalistic and provide little insight into the ways the legal system worked and the many different factors that influenced legal actors and their actions. This formalism is generally exhibited in one of two ways. In the first, an author adopts the classic formalist tenet that rules and logic alone are what decide cases before a judge or other decision-maker. The goal then becomes a dissection of the legal decision, which might be a court decision or fatwa, in order to discern the Islamic (or other) law that produced it. In this type of formalism, the legal rules and doctrine that are deduced from the decisions are enshrined as the sole explanation for the decision. There is no room in this approach to seek to identify social, cultural or political factors that may explain in whole or in part the decision.

The second type of formalistic study in Islamic law is doctrinal. While useful in many ways, these studies should be explicit that they are an attempt to reconstruct the legal rules accepted as authoritative by a particular school of law, or particular scholar, at a particular moment in time. The doctrine itself cannot tell us if and how the rules were applied, by whom and to whom, and the consequences. It may be the case that the legal rules as determined in this kind of scholarship were accepted as authoritative by decision makers and that they strove to apply them. The 
rules may have had little effect in practice and thus such a synthesis of rules is better described as intellectual history.

The area of Islamic legal studies is not the first with a need to address the challenge of legal formalism. A movement called legal realism developed and gained strength at the beginning of the twentieth century in American legal studies in response to the prevailing formalism of that time. The realists challenged the idea that solely legal rules determined the outcome of a legal question, and that the legal rules necessarily produced one "correct" answer. Their concern was with understanding adjudicated results, and they believed that exclusive focus on the legal rules was misguided because judges tend to respond to the facts of the case and what they think is fair given the social context, rather than confine themselves to narrowly applying rules of law. ${ }^{4}$

Legal realism transformed legal studies. As Brian Leiter writes:

By emphasizing the indeterminacy of law and legal reasoning, and the importance of nonlegal considerations in judicial decisions, the realists cleared the way for judges and lawyers to talk openly about the political and economic considerations that in fact affect many decisions. This is manifest in the frequent discussions--by courts, by lawyers, and by law teachers - of the 'policy' implications of deciding one way rather than another. ${ }^{5}$

The legal realists convinced the legal academy that the study of law must include not only the laws themselves but also an understanding of the other factors that influence the legal decision-making process. ${ }^{6}$

The field of Islamic legal studies unfortunately has been slow to appreciate the relevance and usefulness of legal realism to the long-standing dispute in Islamic legal studies over the level of formalism in the application of Islamic law. As is the case in legal systems generally, there is an intellectual step between the law on the books and the law in action, and much room for discretion, consciously or not, on the part of the implementer of the law-whether judge or other - in this step. Beginning with these premises, a study of Islamic law in a particular time and place should ask questions such as: How did the legal system function? How was the relevant law determined in any given case? How was the law applied, by whom, and to whom? What were the factors influencing those officials who applied the law? What was the relationship between the legal text and the context of daily life?

Recognizing the relevance of such factors does not conflict with the religious provenance of the law. However, denying the relevance of social circumstances to the application of the law does a great disservice to the study of Islamic law by turning it into an abstraction. Further, failure to 
consider the applicability to Islamic law of methods from other fields of legal studies leads to the unsupportable notion that Islamic law is exceptional and cannot be studied in a comparative manner.

This article draws upon the lessons of the legal realists and follows in the line of Vogel's work and his call for more attention to law's application. My case study is the application of law by the muhtasib in early Mamluk Cairo and Fustat (648-802/1250-1400). The multasib, best described as an inspector of the markets and public spaces in general, was a legal official charged with "commanding right and forbidding wrong," and was tasked with patrolling public streets, especially in the marketplaces, and enforcing laws as he understood them whenever he encountered a violation. ${ }^{7}$ The realists dealt with judicial decisions, and specifically appellate decisions. The muhtasib is not a judge, of course, but was an applier of the law and resembled a judge in that regard. Even without a perfect correlation to the legal actors with whom the realists were concerned, it is very useful to suggest that the lessons of the realists are relevant to the position of the muhtasib and to any other Islamic legal actor.

This article will examine instances of the muhtasib's decision-making in areas related to food availability and pricing. This implicates the legal rules on price setting and hoarding. The goal is to assess the factors that went into the application process and to show that viewing the particular factual situation alongside doctrine and the general context allows a much fuller explanation of decision-making by the muhtasibs. By including as much traditionally non-legal information as possible for each case; we can see that the muhtasib's actions resulted from a combination of social, economic, and political factors; the potentially applicable laws; and the particular personality of the muhtasib. These results show that a formalist approach to these cases would have resulted in a narrow and skewed perspective of the application of law.

There are many examples in the historical chronicles of the multasib's actions in matters of food availability and pricing in Mamluk Cairo and Fustat, making this topic ideal for this study because of the comparisons and contrasts among cases that it allows. The general population also associated the muhtasib with availability and cost of food. The vast majority of price issues involved the fundamental food stuffs of wheat, barley, and the like, and the final product, bread. For example, in the middle of the year 782/1380, the Nile's rise was not sufficient, and prices of crops rose. People tried to acquire and store food, and general anxiety increased. The people then sought to improve the situation by calling for the dismissal of the muhtasib of Cairo, Shams al-Din al-Damīin, and asked for the return of the previous muhtasib, Jamāl al-Dīn al-'Ajamī. And indeed al-'Ajamī was reinstated, and the people celebrated and rejoiced. The reason for their enthusiasm was that "bread had been difficult to find in the market, 
and for a few days unavailable. They thought that the arrival of al-'Ajami would be a blessing, and it was as they thought. On that day a number of ships laden with crops arrived and the prices decreased."

This report reveals that the muhtasib was linked in the minds of the people with prices and availability of food. Even without a tangible causal link between the new mutasib and the arrival of goods (for they most likely had left their point of origin before al-'Ajami was reinstated), he gets the credit for the new food and decreasing prices. ${ }^{9}$ As will be seen in the cases that follow, when prices rose and food was unavailable, the people often held the muhtasib responsible, as did the Sultan. ${ }^{10}$

A significant characteristic of the grain market was that the Sultan and the amirs controlled large amounts of grain and other agricultural products, which had a substantial effect on the market. Part of the taxes collected in kind by the central government was "assigned to emirs, Mamlūks, and other officials of the state as direct payments of salaries and compensation for expenses incurred in the fulfillment of their duties."11 Such assignments (iqtat $\bar{s}$ ) "remained the largest claim on the grain produce of Egypt in the Mamlūk period." ${ }^{\prime 2}$ These grain owners depended on the market to acquire income to purchase other items they needed. ${ }^{13}$

Price setting and hoarding of food are standard topics in texts of Islamic jurisprudence $(f i q h)$. The jurists agree on the general rule that price setting is prohibited. ${ }^{14}$ The proof for this is the widely-cited hadith:

The prices were high in Medina at the time of the Prophet, and the people said to him: Messenger of God, the prices are high, so set prices for our sake. The Messenger of God said that God is the establisher of prices, the one who contracts and expands the market, and the one who provides subsistence. I want to meet God free from any claims against me that I oppressed any one of you in terms of person or property. ${ }^{15}$

There were exceptions to this general rule, and the Maliki school was the most permissive overall in allowing the ruler to set prices when serving the public interest required it. ${ }^{16}$

While price setting is usually discussed in contexts of high prices, scholars treated the issue of raising prices in the same manner as lowering prices. According to the Malikis, the price prevailing in the market is to be respected, such that if one or a few sellers reduce their prices to lower levels, they are ordered to either return to the prevailing rate or leave the market. The proof text for this rule is a hadith according to which 'Umar b. al-Khatțāb passed a man selling raisins in the market, and he told him: "Either raise the price, or leave our market."17

The other Sunni scholars rely upon a longer version of this same hadith as proof that price setting of any kind is impermissible. According to this 
version, when Umar returned home from the encounter in the market with the raisin seller, he reconsidered the situation and then summoned the merchant and said to him: "What I said to you today is neither a decision nor a ruling from me, but only something that I wanted in the interest of the people of the town. Sell wherever and however you want." 18

A related legal topic is the hoarding of goods and the penalty imposed upon the hoarder. There was disagreement among the Sunni schools of law about virtually every aspect of the laws of hoarding, such as what goods were protected by these laws, and what penalty was to be imposed on the hoarder. In general, though, scholars agreed that essential food, such as wheat and bread, was covered by the rules prohibiting hoarding. ${ }^{19}$ Scholars who took a less aggressive approach to the remedy would simply require that the hoarder sell, and if the hoarder refused, they would demand punishment of the hoarder such as through imprisonment. Scholars following this approach would not advocate a seizure of the goods and sale of them at the set price, on grounds that this would be a taking of property. Scholars with a more forceful approach to remedies for hoarding prescribed forcible sale of the hoarders' goods, and a return of the proceeds to the hoarder.

\section{Case Study 1: Price Setting and Hoarding at the Fustat Granaries '}

A significant case of grain prices that involved the muhtasib in the period studied occurred in 736/1336, during the third reign of Sultan al-Nāsir Muhammad (709-41/1310-41). The reports of this episode are full of details about the role of the muhtasib, his jurisdiction, his relation to the Sultan and amirs, and the way that those in power applied the law.

Events began with reports of rising wheat prices, from fifteen dirhams per irdabb $b^{20}$ to twenty and then to thirty in a short period of time, such that people's daily lives were greatly affected. The price continued to rise, to forty dirhams per $i r d a b b$; the amirs and others with grain stocks then refrained from selling, expecting a continuing rise in price. The Sultan feared the consequences of this, and so when wheat reached fifty dirhams per irdabb he called for Najm al-Din, the muhtasib of Cairo, and criticized him. Najm al-Dĩn served as muhtasib from 720/1320-21 till his death in $737 / 1336$, and we may conclude that by this time, just shortly before his death, he was not as energetic and able as the Sultan would have wanted him to be. The Sultan did not replace him, though, but supplemented his work by empowering the governor (wālin) of Cairo, 'Alä' al-Dīn al-Marwānī, to act alongside the muhtasib. ${ }^{21}$

And the governor did indeed take action. He beat a number of millers and bread bakers with whips, but the situation just worsened. Shops in Cairo and Fustat closed, and bread could only be bought with great hardship. People crowded around each bakery in such force that the 
governor had to station guards to keep order. ${ }^{22}$ The Sultan ordered that grain be brought from Gaza, Karak, Shawbak, and Damascus, and it was announced in Cairo and Fustat that wheat was not to be sold for more than thirty dirhams per irdabb, and whoever sold for more than that would have his property confiscated (perhaps referring to the profit, the sale amount or all of his grain). The Sultan ordered the amirs not to violate this order. But the amirs and brokers of grain merchants refrained from selling at all, and the situation deteriorated. Brokers secretly sold for sixty and seventy dirhams per irdabb, and amirs took grain from their storehouses on the grounds that it was to supply the daily needs of their households, but they were probably selling it on the side at a higher price..$^{23}$

The Sultan was distressed by the people's suffering, and knew that the amirs controlled most of the grain. He summoned Diya al-Din, whose abilities in the service of the state were well known, and appointed him muhtasib of Fustat, after he had initially refused the position. ${ }^{24}$ Diyä' al-Din went with the notoriously brutal amir Sayf al-Din Alakuz ${ }^{25}$ to Fustat, and the first thing Diya al-Din did was record how many irdabbs were in the storehouse of each amir and how much that amir would need to provide for his household and animals until the time of the arrival of new crops. Then he sealed all of the storehouses of the amirs and summoned the brokers, guards, and grain measurers and made them swear that they would not open the storehouses except with the muhtasib's permission. ${ }^{26}$

Every day Diyâa' al-Dīn would go to the storehouses and take out grain, and began by providing it to the millers at thirty dirhams per irdabb, which was the maximum price for all grain sales per the Sultan's earlier order. But brokers of the amirs Bashtāk and Qawșun were violating these rules and selling for more than thirty, and so the amir Alakuz was called to Fustat whereupon he flogged the brokers with whips and exposed them to public disgrace. When the Sultan was informed of their transgression, he too punished them severely. After that, no amir dared to open his storehouse without the muhtasib's permission. ${ }^{27}$

At the same time, the Sultan, who was making efforts to bring more grain into the city, ordered the governors of the regions to bring all grain available to Fustat to be purchased at thirty dirhams per irdabb. Despite all these measures, however, the Sultan learned that some amirs were still hoarding their grain from the market and selling outside of the established regime. But the neighbors of these storehouses helped out, either by raiding their supplies or by turning them in to the governor, who took what they had and distributed it to the millers. ${ }^{28}$ A witness was sent to each oven to monitor the amount of wheat brought to it, and efforts were made to ensure equal distribution of bread around the city. The people's agitation from the difficulty in finding bread decreased, as did the floggings of millers and bakers. The arrival of shipments of grain from Damascus and then Upper Egypt brought the crisis to an end. ${ }^{29}$ 
This event involved both price setting and hoarding. At first, the Sultan announced that grain could only be sold for thirty dirhams, which is a pricesetting order. If the scholars who permitted price setting when the public interest dictated it had been asked to give an opinion on this action, it is likely that they would have authorized the Sultan's action given the terrible state of affairs reported by the chroniclers. Even at that time, the reports convey a sense that merchants were not selling their wares, yet the case was not treated as one of hoarding at this early stage. The price had risen from fifteen to fifty dirhams, grain owners were refraining from selling, and the people were greatly affected. The price-setting announcement did not come from the muhtasib, however. This was a large-scale crisis, encompassing both major cities and requiring grain to be brought from other parts of the sultanate, so it is not surprising that the price setting came down from the highest level. In case of smaller problems, as will be seen below, it was more than likely the muhtasib who announced the price..$^{30}$

The Sultan ordered the amirs and grain brokers to obey this order, but in response they refrained completely from selling - the situation then became fully a problem of hoarding. The hoarding could have been addressed earlier. Indeed, when appointing the new muhtasib, the Sultan knew that the amirs controlled the grain and that they wielded enough power that they might simply refuse to sell. Nevertheless, it appears that the Sultan was not prepared to, or did not yet think it necessary to, directly confront the amirs and instruct them to actually sell. The Sultan called in Diya $\vec{a}^{3}$ al-Din to command hoarders to sell, and he required that the sale price be thirty dirhams, the same as the Sultan's price-setting order.

The prominent role of Fustat and its muhtasib in this event is noteworthy. The muhtasib of Cairo was not replaced, but was reinforced by the governor of Cairo, who for all practical purposes superseded him. ${ }^{31}$ As a result, the position of the muhtasib of Fustat now took on critical importance in the matter, and the Sultan convinced an individual who was known for his capabilities to take the position. Correspondingly, the storehouses of Fustat were where the real action took place, and they were needed to supply both Cairo and Fustat. The Cairo grain market seemed irrelevant (although, of course, not Cairo's bread market and the needs of Cairenes). Perhaps Cairo's storehouses were depleted before those of Fustat. ${ }^{32}$

Fustat's significance in the event was due to its port and grain storehouses, with al-Maqrīzi reporting that grain arrived at the docks of Fustat, not of Cairo. ${ }^{33}$ Between the time of the decline of Maqs as Cairo's port and the development of Bulaq, Fustat was a significant port for grain arriving from Upper Egypt, and its granaries were located near to its banks. ${ }^{34}$ These were the granaries at issue in the event, and so the Sultan needed a muhtasib in Fustat to deal with them. It would not be efficient to divert the muhtasib of Cairo to the task, and leave Cairo without this important regulator at a time of food crisis. 
Another important aspect of this event is the relationship between Cairo's muhtasib and governor and the relationship between Fustat's muhtasib and the amir Alakuz. Neither muhtasib carried out the heavy punishments, but had their tough man for that task. It was not at all unusual for a multasib to take care of light punishments, but then turn over the offender to someone else, such as the Sultan, an amir, governor or judge, for more significant discipline. This practice may have been due to the muhtasib's preference not to get too involved in the dirty details of the punishment.

This event could be boiled down to a case of price setting due to public necessity and an aggressive approach to hoarders who refused to sell. And indeed fiqh texts could be used to argue that the actions of the Sultan and muhtasib are attributable entirely, and even solely, to the legal rules themselves. Such a formalistic reading is possible but imprecise. Many other factors came into play alongside legal rules to produce the effects. The Sultan played a prominent role in the controversy, and announced the set price himself. The Sultan backed fully his newly appointed muhtasib. This is the only case studied of a successful response to hoarding. The success can be explained by the fact that the Sultan and muhtasib were strong enough to together confront the amirs. The Sultan could have claimed that hoarding was occurring much earlier in this event and attempted to take action, but other examples of failed attempts to force hoarders to sell suggest that the Sultan was prudent to wait until he had his strong muhtasib in place. The event is explained more by the personalities involved than by the rules of hoarding.

\section{Case Study 2: An "Agreement" on Wheat Prices to Please the Political Powers}

In $738 / 1337$, the price of agricultural produce decreased to the point that an irdabb of wheat from Upper Egypt was sold for ten dirhams, an $i r d a b b$ of wheat from Lower Egypt for eight dirhams, and beans and barley for six dirhams per irdabb. Even at these prices, sales were stagnant. The affairs of the troops (jund) came to a halt as a result of the low prices since troops were paid in wheat and had to sell it on the market to acquire other products they needed. In an effort to earn a little more money, the brother of al-Nashw, the supervisor of the fisc, along with an accomplice, forced (tarh) merchants to buy their wheat for an extra two dirhams per irdabb.

Separately, al-Nashw complained about Diyā' al-Dīn, muhtasib of Cairo, because the price of flour and bread was high in comparison to the price of wheat. ${ }^{35}$ The millers were the ones benefiting from the situation, it seemed, because they were buying cheap wheat but then selling flour at a disproportionately high price. The price of bread, then, reflected the price of the flour. There did not seem to have been complaints by consumers about bread prices. But the powerful al-Nashw was displeased by the low wheat prices and the effect it was having on the military troops. Al-Nashw 
then ordered the governor of Gairo to summon the muhtasib and the millers and work out an average price of wheat, so that there was not such a difference in price between wheat and bread. ${ }^{36}$

Al-Nashw's brother's tactic was employed by later amirs and even sultans when they wanted to sell their grain at high prices, but it was not yet widely used at this time. Instead of simply dictating higher prices to the millers and requiring them to buy at that price, the muhtasib was ordered to work with the millers to come to a new price. This kind of price agreement strongly suggests that the muhtasib negotiated with the grain merchants and millers to come to a fair or just amount for the sale of wheat and every subsequent by-product to the bread sold to consumers. Unfortunately for consumers, they seem to have received no benefit from low wheat prices.

Muhtasibs, even strong ones, sometimes gave in to pressures from amirs, and this example demonstrates how law was at times caught in the middle of power politics. But al-Nashw was something of a special case, and by this time, he had an ample reputation for oppression. ${ }^{37}$ Shortly after this event, he was able to secure this muhtasib's dismissal. This is the first indication of an amir interfering so directly in the appointment or dismissal process for the position of muhtasib..$^{38}$ In light of al-Nashw's particular power, his interference with pricing here is more easily explained and understood.

Some jurists who permit price setting state that the price should be determined through negotiations between the producers and the muhtasib or political leader. The producers should not be denied some profit, they argue, or they will have no incentive to produce in the future. Others do not require such a consultative process. One way to understand these events is to argue that al-Nashw wanted the muhtasib to discuss prices with the millers in order to follow the consultative line of thought about price setting. A formal look at the events could produce that explanation. But knowing the background and personality of al-Nashiw, it is difficult to interpret his decision in any way other than that he.was seeking the best possible outcome for himself and the troops. Had he known what price of wheat would produce that outcome, he might have instructed the muhtasib to require the millers to buy at that price. Without an understanding of market dynamic, he had to order the muhtasib to consult with the millers in order to determine the ideal price from his own perspective. The millers were apparently willing to enter into these discussions due to al-Nashw's political power.

\section{Case Study 3: Price Setting in Order to Raise Bread Prices}

A few months after Ibn al-Uțūsh was appointed muhtasib of Cairo in $748 / 1348$, he was greeted by a hail of stones from the people. The reason was that at a time when the price of bread increased and one dirham 
purchased only six to seven ratls of bread, some of the bakers sold eight ratls for one dirham, that is, slightly cheaper. Ibn al-Utrūsh summoned these discount bakers and beat them. The people were angry with the muktasib and they threw stones at his door until the governor came and beat them away. ${ }^{39}$

This case highlights the complex network of prices, although the chroniclers recorded very little information about the details. We do not know why prices were six to seven ratls per dirham, but given the muhtasib's reaction to the lower prices by a few bakers and the reaction of the people against efforts to keep prices higher, we may presume that there had been instability in the prices of bread prior to this event and that everyone was worried about maintaining a stable rate that was reasonable from their individual perspectives. The rate must have still been unstable, since the muhtasib perceived one or a small number of under-sellers to be a threat.

Another possibility is that the muhtasib was concerned primarily about the prices of grain on behalf of the amirs and other grain owners. Falling bread prices would eventually affect grain sales and would cut into the profits shared by grain owners and their brokers, along with millers and bakers. This possibility seems plausible since this muhtasib was more attached to the ruling elite than most others of this period. His professional career began in Damascus, where in 744/1343 he was appointed its muhtasib. He gained that position, however, with the assistance of an. amir, and the people there were upset with his appointment due to his ignorance of Islamic law. ${ }^{40}$ While serving as muhtasib of Cairo, in 749 he was appointed military judge in the Hanafi school and held that position until his death. ${ }^{41}$ His appointment and long service as military judge is also a good indicator that he was well connected to the Mamluk regime.

The schools of law disagreed about how the person who sells below the prevailing market price is to be treated. According to the Malikis, the school that was the most permissive on the ability of the leader to set prices, the price prevailing in the market is to be respected. If one or a few sellers sell under it, they are ordered to either return to the prevailing rate or leave the market.

In this case of the bakers selling eight ratls of bread for a dirham when the going rate was six to seven ratls for a dirham, the muhtasib Ibn al-Uțrüsh physically punished the under-sellers to prevent them from conducting their transactions at this rate. A more sophisticated muhtasib might have followed 'Umar's example and warned that if they did not raise their prices, they would have to leave the market. This strategy would only be effective if the merchants respected, or feared, the muhtasib and would fear the consequences of disobeying him. An ignored verbal order would have been an embarrassment to the muhtasib. Perhaps knowing what would happen if he simply issued a command, Ibn al-Utrusush went straight to the level of physical punishment without trying a verbal admonishment first. Not 
surprisingly, the bread-consuming public became angry, saw the multasib as working against their interests, and threw stones at his door.

This case highlights the way in which the demands of various interest groups related to one another. If the price of bread dropped, it would eventually affect the price of grain, which was owned by the amirs. Ibn al-Utrūsh had built his career not through scholarship or even by being a solid bureaucrat, but rather by currying favor with the amirs in power. In this light, it is not surprising that as muhtasib, he was less worried about the people's access to affordable bread than about his own status with his patrons.

A formal view of these events could demonstrate that the muhtasib was trying to keep the market for bread and its raw materials stable. In doing so, he could not allow merchants to sell bread at costs above the market rate or perhaps even the rate the muhtasib had set himself earlier. He set prices either of his own accord or due to an order of the Sultans or powerful amirs, and since at least the Malikis might have allowed this, we could conclude that the muhtasib was simply applying the law most applicable to the situation. But such an interpretation ignores the many different factors that seem to have caused the reported result. In particular, the personality of the muhtasib is significant. Had the muhtasib been someone whose fortunes were not too intimately linked to the amirs, perhaps this event never would have happened.

\section{Case Study 4: The Consequences of Lowering Bread Prices}

Shams al-Dīn al-Damīrîs appointment as muhtasib of Cairo in 776/1374 came at a time of increasing prices due to concern over the inadequacy of the Nile's rise. The prices of wheat (100 dirhams per irdabb), barley (60), and beans (50) were troublesome to the people. A few days after Shams al-Din's appointment, he dispatched a number of carriers with loads of bread, and they traversed Cairo up to the citadel accompanied by drums and cymbals. It was announced that two and $3 / 4$ ratls of bread would now cost one dirham, whereas the price had been two and 1/3 ratls for a dirham. With this parade of bread, Shams al-Dinn was clearly trying to show to the people that as muhtasib he would take charge of bread prices and make this basic product affordable. And the people were happy-except that bread could not be found in the markets for five days, and people crowded around the ovens in search of it. ${ }^{42}$

With the people in despair, it was ordered that more bread be made and sold without a set price. The prices of foodstuffs rose, and by the beginning of the next month wheat reached 110 dirhams per irdabb. Within two weeks, al-Maqrizin was reporting the beginnings of an epidemic, and deaths of the poor from hunger were numerous. ${ }^{43}$ The cause or the nature of the epidemic is not given, but al-Maqrizîs use of the term indicates that 
it was more than a case of some deaths due to lack of food. Inadequate diets probably allowed an illness to find easy victims among undernourished people and thus spread quickly. By the month of Ramadan, the disease had spread to the wealthy as well, and the prices of luxury goods, like chickens and melons, also increased. Hunger and death were rampant. ${ }^{44}$

Two months later, though, new supplies of wheat arrived and prices decreased, with bread being sold at four ratls per dirham. ${ }^{45}$ When the situation began to improve, or at least the rate of death slowed, Shams al-Din, who had remained in the position of muhtasib throughout the crisis, declared the price of bread to be eight ratls per dirham, up from five and $1 / 3$ ratls per dirham. The millers then refused to purchase wheat for more than eighteen dirhams per irdabb. Because of the low price of bread, the bakers would only be willing to pay so much for flour, which meant that the millers could not pay more than eighteen dirhams for an $i r d a b b$ of wheat and still supply the bakers without a loss. The importers refused to sell for such a low price, and they returned in their boats with their goods to the places from which they came. The absence of wheat in the market caused the price to reach 34 dirhams per irdabb. Then bread could not be found for a few days and when it was available, it was sold for less than six ratls per dirham. ${ }^{46}$ With a brief mention that the epidemic then abated, al-Maqrīzi ended this long narrative on rising prices and the spread of disease. ${ }^{47}$

The multasib's actions were not very effective in this case. He focused on the part of the problem most visible to the people-the price of bread-and neglected to acknowledge that the price of bread is related to the price of flour, which is connected to the price of wheat. He also unilaterally set prices when there were difficulties in the market but no signs of a crisis, which is the classic price setting prohibited by law. If there were any domestic wheat supplies being hoarded, the muhtasib did not try to regulate the price and their availability so that it was possible to sell bread for the amount he specified.

In any case, the price of wheat was a much more difficult issue, since the amirs controlled so much of the market. Most likely, it would have required a firm order from the Sultan to deal with the grain prices on a macro level, either by aggressively searching for new supplies or giving his backing to forcing amirs to sell what supplies of grain they had. At this time, however, the young Ashraf Sha'bān was Sultan, and his authority was under growing threat from Barqūq, who would ultimately seize the sultanate for himself. The ability of Sultan Ashraf Sha'bān's state to take control of the situation may have been limited by his own tentative status. Furthermore, the implementation of such an order would require a strong muhtasib, and people probably lost confidence in al-Damīri after he could not deliver on his first attempt to control bread prices. 
In the second wave of the crisis, we get a valuable piece of information about the importers of wheat. Importers arrived with much-needed wheat, but they would not sell for the low price the local millers. were offering. Significantly, there is no mention of the muhtasib trying to force the importers to sell their wheat at a price the local millers could afford to pay. There was recognition that importers were outside of the regulatory framework, and that they had the right to turn around and sail away, in search of a better market. The Sunni schools of law agreed that the importers played a special role and that they were not subject to any price controls in effect in the market. They had the right to decide if they wanted to sell in the particular market. If they were forced to comply with local rules, then they would not return to that market for fear of being forced to sell, or forced to sell at a specific price. Even the Maliki muhtasib Shams al-Din al-Damīī, who set bread prices on other occasions, did not attempt to control the importers sitting at the port and deciding whether they wanted to sell to the Cairo merchants.

This complex report could be reduced to the legal explanation that the muhtasib simply set prices when he had no legal justification for doing so, since even for the Maliki school there has to be a public interest at stake in order to set prices. At the beginning of the report the situation seems like one of rising prices but not a crisis. This conclusion would lend support to the idea that a liberal use of price setting is not only illegal but also bad from the perspective of the outcome, since in this case the result was a worse situation for the consumers. In examining this event, a narrow reading would leave out the important detail that the muhtasib focused on bread, and not its component ingredients, to regulate. His misunderstanding of the market, more than any ignorance of the law, explains this event.

\section{Case Study 5: A Muhtasib's Struggle to Retain Authority}

The case discussed here is preceded by the suggestion that Sultan Barqūq was imposing grain sales to acquire funds for an expedition to Damascus. ${ }^{48}$ Then at the end of 796/1394, the Nile failed to reach its expected level, and prices rose in anticipation of shortages to come, with wheat increasing to 40 dirhams per irdabb. The people shouted at the muhtasib Ibn al-Burji, complained about him to the Vice-Sultan $(n \bar{a} \vec{\imath} b)$ Sūdūn (Barqūq being in Syria by this time), and, according to one report, even wanted to stone the muhtasib. So the Vice-Sultan ordered the governor of Cairo, amir 'Alä' al-Dīn al-Țablāwī, to take charge of the matter of prices. ${ }^{49}$

The governor ordered the storehouses to open and sell at "God's price." He threatened those who did not open their storehouses and sell within three days with seizure of their goods, presumably to be sold. The agents of the amirs obeyed, and the price came down a little,$^{50}$ but they soon slowed down their selling, and the fear of famine increased. ${ }^{5 !}$ 
This case is difficult to describe as one of drought or serious shortage in the city's food supply. While the rising prices were inconvenient and some people were not selling, it was not the same level of crisis as seen in other examples, and in particular there was no evidence that people were suffering because of the failure of merchants to sell. Instead of working through the office of the muhtasib and supporting the muhtasib's authority to manage or at least monitor the situation, the Vice-Sultan threw up his hands and told the governor to deal with the problem.

But governors did not typically handle these kinds of matters, and the governor probably had little awareness of the details of market practices, policies or rules. So it is not surprising that, in broad sweeping measures, he ordered the opening of storehouses and sale at "God's price." This was the easiest order the governor could give, because it had little content. "God's price" is a reference to the well-known statement by the Prophet that "God is the price setter" and thus the Prophet would not set prices himself. ${ }^{52}$ So the governor commanded that the merchants sell but he would not specify the price. The result was not a major success, for although the merchants did sell some grain, prices only decreased slightly. This exposes the limitations of requiring sales without announcing the price. On the one hand, it does not force grain holders to sell at a price so low that they will employ all kinds of tricks to avoid selling, but on the other, it does not cause a major change in the market to make goods more affordable and available to the people.

The muhtasib was clearly bypassed in this matter, with the Vice-Sultan directly ordering the governor to assume responsibility for the matter of prices. ${ }^{53}$ Perhaps the Vice-Sultan lost confidence in Ibn al-Burjī when the people complained about him, yet he did not replace the muhtasib or ask the governor to work with him (as in the case of the Fustat granaries) but rather treated him as irrelevant.

Ibn al-Furat provided an insightful postscript to the affair: The judge Sa'd al-Dīn al-Baqrī found fault with the governor for his order to open the warehouses and sell at "God's price" and for getting involved in what is related to the muhtasib's affair. The judge threatened to inform the Sultan of the governor's actions, whereupon the governor ceased his involvement after the prices decreased a little and the people were reassured by the decrease. ${ }^{54}$

With this information, we are able to enter the domain of competing jurisdictions and professional rivalry. This governor of Cairo was ambitious, and Ibn al-Burjī ceded his authority very easily. The judge's complaint shows that in the Mamluk bureaucracy, there was a conception of the muhtasib's sphere of authority and that an incursion into it was unacceptable to some, or at least the results of it were unacceptable. Was this judge standing up for the muhtasib's jurisdiction and what that meant for closer adherence to the law? This problem of high prices did 
not fully resolve itself with the governor's actions, and throughout the year $797 / 1395$ there were reports of high prices and a slow economy, leading to the next event.

This case could be described as one in which someone finally understood the law. The order to sell at God's price indeed comes from the hadith in which the Prophet refused to set prices. Rather than impose a price, the governor basically told everyone to sell at the price of their choosing. It would be easy to conclude that this case shows that leaders in the Mamluk Sultanate knew that the law viewed God as the price setter, and thus humans were to refrain from acting in this area. This interpretation would ignore the individuals involved, as well as the fact that the governor probably did not know what price to impose in order to be effective. Enough ineffective price-setting events had occurred by this time that it must have been known that unless all of the right factors line up, the price-setting effort will fail.

\section{Case Study 6: A Muhtasib Challenges the Political Powers}

At the beginning of $798 / 1395$, the price of wheat came down to 60 dirhams per irdabb and the people were happy. ${ }^{55}$ But then due to forced sales, the price rose to $110 .^{56}$ The chronicler Ibn al-Furāt explained that there was a dispute between a powerful amir and al-Bakri, muhtasib of Fustat, over the forced sale of wheat at a high price "in excess of the limit" (al-zä'd 'an al-hadd). ${ }^{57}$ Al-Bakrī resigned from the position of muhtasib of Fustat and, in what must have been a daring move, sat in the mosque of 'Amr b. al-'Ās, and told the people: A powerful amir "summoned me on account of the forced sale of wheat. They had imposed it at the price of 80 dirhams per $i r d a b b$, then 90 , and the people were sad because of that. And he told me to impose it at 110 dirhams, and I resigned."58

This indicates that the muhtasib had been taking part in forcing sales. The Sultan heard of this affair while he was in the Cairo suburb of Siryāqus, summoned al-Bakrī, and reinstated him to the position of muhtasib of Fustat. He also decreed to give to al-Bakri and to the muhtasib of Cairo $10,000 \mathrm{irdabbs}$ of wheat to be imposed on the millers at the price of 100 dirhams per irdabb. ${ }^{59}$

The situation of food prices and availability did not improve, and the Sultan undertook to provide large amounts of bread to the poor. ${ }^{60} \mathrm{~A}$ major problem was the lack of additional food coming into the market. In Cairo and Fustat, prices were high due to shortages of goods and for seven days bread could not be found in the shops. Wheat was sold for 175 dirhams per irdabb and flour for 200. Bread, when found, was sold for one-half dirham for one ratl of bread. ${ }^{61}$

And then the event that all had been waiting for happened-ships filled with produce arrived at the docks of Cairo and Fustat. ${ }^{22}$ With the 
abundance of imports, prices decreased, to the point that wheat was sold for 50 dirhams per irdabb and four ratls of bread for a dirham. ${ }^{63} \mathrm{Ibn}$ al-Furāt added that if it were not for forced sales, the price would have decreased even further. ${ }^{64}$ This statement must indicate that while the new arrival of goods would have allowed for a fall in prices as demands were met, wheat belonging to the Sultan or amirs was being imposed on some merchants at a price higher than what might have occurred naturally, and this was keeping average prices up. The merchants were forced to absorb the "cost" to the Sultan and amirs of the low grain prices.

Low prices created another problem-the grain importers were displeased and realized that at these falling prices they would not be able to recover their capital investment and the expenses of their travel. They refused to sell in Cairo and Fustat and went off to Alexandria, in search of higher prices. Seeing that the supply of grain was slowing, the millers and bakers produced less bread, and the people, seeing this, rushed to try to buy bread and suffered from these efforts. ${ }^{65}$

The people went to the Sultan and complained about the lack of food, at which point the Sultan ordered the amir al-Tablāwi to take control of the matter. ${ }^{66}$ Ibn al-Furāt added that Barqūq specified that al-Tablāwi should punish millers and brokers and that the muhtasib al-Damāminni (who had been appointed four months earlier) should beat four of the biggest millers and sellers of bread with whips and sticks and order them to increase production of bread. But these millers and sellers did not heed the muhtasib, and the matter worsened. ${ }^{67}$ Then it was ordered that a loaf of bread should be sold for one-fourth dirham, and the people desperately sought and fought with each other for it. ${ }^{68}$

The muhtasib of Cairo, al-Damāminni, noted the rise in prices, the lack of goods, and how the city was reacting to the situation. He hid at home for three days out of fear that the people would attack him. Al-Tablāwi

- had to rescue him from his home and protect him from a. near stoning by the people. ${ }^{69}$ The Sultan dismissed al-Damāminnī and appointed Shams al-Din al-Makhānasī ${ }^{70}$ with the mediation of al-Tablāwī. There were two significant aspects to this appointment. First, as al-Maqrīzi reported, it was without the payment of money, which by that time had been a common condition imposed for appointment to public office. ${ }^{71}$ Secondly, according to Ibn al-Furāt, al-Makhānasī actually stipulated as a condition of his appointment that he would not be required to impose forced sales. ${ }^{72}$ The people celebrated his appointment, although the situation took some time to improve.

Three aspects of his appointment are very significant. First, the Sultan must have been desperate enough for an effective muhtasib that he was willing to forego a payment to the Sultan from the new muhtasib that by this time had become fairly typical. Secondly, the new muhtasib saw that his predecessor had nearly been killed by the people and attributed the 
problems in the food pricing and supply system in large part to the forced sales that the muhtasib had in the past been responsible for carrying out. Third, the previous muhtasib had played a role in forced sales, at least for some time. He participated under pressure, it seems, but he was pushed to his limits by the Sultan and finally refused to go further. This new appointee had enough bargaining power-although we are not told why-in order to secure that, at least in theory, he would not be required to do this. ${ }^{73}$

We do not know if the previous muhtasib objected to the forced sales for pragmatic reasons or because he thought they were illegal. The jurisprudence on hoarding and price setting does not discuss a political leader forcing sales of his own goods on merchants at inflated prices as a way of raising revenue for the leader or his officials, such as the amirs. In a way, these forced sales (tarh or rimaya) are a tax on the merchants, because they purchase the goods from the Sultan or amirs at a rate that is above market, then sell those goods to the public, usually for less than they paid. The difference is for the benefit of the Sultan at the merchant's expense. This can be distinguished from setting prices or forcing a hoarder to sell, because there are no proof texts that offer justification for tarh or rimāja, and extra (and illegal) taxes have been condemned in the law books and manuals.

This case could be seen as a triumph of the law over political power, and perhaps in this one case it is a fair characterization. By this point in time, however, sultans and amirs commonly used the tactic of forcing sales at inflated prices upon merchants. This is the only recorded case in which a muhtasib resisted involvement in this illegal practice. As the Mamluk Sultanate declined in power throughout the 1400s and the corruption of the sultans and amirs increased, the position of the muhtasib also declined. This study ends in 1400 , but it is well documented that the muhtasibs of the Mamluk Sultanate in the fifteenth century were almost without exception linked to the amirs; indeed, amirs even held the position of muhtasib.

\section{Conclusions}

We can imagine ways in which these case studies could have been examined only with legal rules as stated in figh texts. Lengthy and contorted interpretations could have been developed in an attempt to explain how the muhtasib applied the law to the particular case without any mention of the social, political or economic background factors, or any discussion of the identity of the muhtasib. I could have constructed an elaborate jurisprudence that tried to bring all of the idiosyncrasies of the situations somehow under the formal heading of the law. But such a study would have resulted in the concoction of a jurisprudence that is unpersuasive and, if brought to bear on another case of the muhtasib and food pricing and availability; would have no explanatory power. 
Alternatively, we can conceive of the conclusion that the muhtasibs simply knew nothing about the laws they were supposed to be applying. The chroniclers did not describe the muhtasibs pondering over fiqh books, and in the absence of this information we have to assume that their decisions were arbitrary. Any hint that the laws were known and relevant was a mere coincidence. Under this approach, the Mamluk Sultans were following their own interests only, and the muhtasibs, who sometimes did come from the class of religious scholars, in turn just carried out the Sultans' orders. Since Islamic law is a religious law that should have been formally applied without room for human intervention, according to this line of formalist thought, if it was not applied in an ideal way, then it must not have been applied at all.

Neither of these approaches is meaningful, and both avoid the social context of the law and its application. We do not have evidence that the muhtasibs were consciously and painstakingly applying what they thought was relevant law, but we also do not have evidence of widespread neglect of the law. A prudent conclusion from these case studies is that the actions taken by the muhtasibs and others in power in these cases are explained by extra-legal factors and legal factors. The scope of analysis must be broad, as I have shown, and must include a far bigger picture than just the muhtasib, the particular facts of the case, and the works of fiqh. Searching deep and wide for relevant information in each case allows us to see that in addition to the law, other causal factors included the willingness of the Sultan to lend the enforcement power of the state to the problem; the cleverness, popularity, and respect of the muthtasib; and the overall availability of grain in the cities (albeit hoarded) and in the Sultanate.

This article also concludes that scholars of Islamic law can and should make productive use of the lessons of the legal realists. It also strongly encourages Islamic law scholars to place themselves in the context of the larger field of legal studies, and to consider the applicability of developments in other areas of legal studies to Islamic law scholarship. Legal systems involving Islamic law have unique attributes, but they are still legal systems and must be recognized as such. This article has shown that an approach born in twentieth-century American legal studies greatly assists us in understanding an instance of the application of medieval Islamic law.

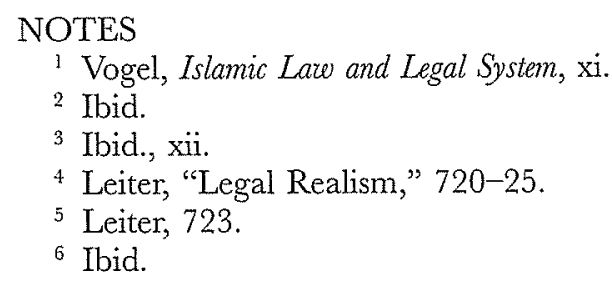


${ }^{7}$ Michael Cook thoroughly examined the Qur'anic injunction to command right and forbid wrong as it is incumbent upon every Muslim in his Commanding Right and Forbidding Wrong in Islamic Thought. He dealt with the individual obligation, though, and not how it operates when the specific official of the muhtasib is charged with undertaking it.

${ }^{8}$ Sulük, 3:395.

9 They also could, of course, have been hovering a short distance away from the docks.

10 This was not always the case - there are numerous reports in the historical chronicles of food shortages and high prices, albeit in less significant cases, without any mention of the muhtasib. The explanation may be that the muhtasibs were more likely to be involved in serious cases or those with unusual circumstances, and the chroniclers were keen to report such cases. Another possibility is that for the less serious cases, chronicle reports were shorter and less likely to include full details.

$"$ Lapidus, "The Grain Economy of Mamlūk Egypt," 3-4.

12 Ibid.

${ }_{13}$ Ibid., 2; Shoshan, "Grain Riots and the "Moral Economy'," 463.

it Figh Encyclopedia, "Ta'sīr."

15 Transmitted by Anas b. Mālik. Sunan Ibn Mäjah, 2191; Sunan al-Trrmidhī, 1235; Sunan Abì Däzeüd, 2994 (all hadìth citations refer to Marosǘat al-hadìth al-shañ̄f).

16 Figh Encyclopedia, "Ta'sir."

17 al-Mureatta', 1164.

${ }^{18}$ al-Himyarī, 'Abd al-Razzāq, al-Mușannaf, 14906.

19 Figh Encyclopedia, "Thtikār."

20 A unit of dry measure.

${ }^{21}$ Sulük, 2:394. Al-Maqrīzī described this wälī as an oppressive tyrant.

22 al-Maqrīzī, Ighätha, 33-4.

${ }^{23}$ Sulük, 2:394.

${ }^{24}$ Lapidus states that the Sultan "appoint[ed] a new market inspector with full powers." Lapidus, Muslim Cities in the Later Middle Ages, 54. Sabra states that the Sultan appointed a new muhtasib "with wide powers." Sabra, 145. There is no evidence, however, that Diyā' al-Dīn was granted any special powers with his appointment. Rather, he was known for his abilities in public office; apparently it was because of these abilities that he was a good candidate for muhtasib of Fustat at time of crisis. He was not given wider powers than other muhtasibs, but was able to accomplish more in the position.

${ }^{25}$ The amir Alakuz was "the torture officer for al-Nāșir Muhammad" and "admit[ted] being a ghutmi [a "disparaging term - to describe those Mamluks who failed to learn proper Arabic"] to emphasize his rudeness." Rabbat, "Representing the Mamluks," 70-1 and n. 34.

${ }^{26}$ Sulük, 2:394-95.

${ }^{27}$ Ibid., 2:395.

${ }^{28}$ Ibid., 2:395-96.

${ }^{29}$ Ibid., 2:396.

${ }^{30}$ The Sultan at this point in his reign also was better placed than some Sultans discussed below to take tough comprehensive measures. 
31 In addition to the apparently lesser role of Cairo in this crisis, the identity of the muhtasib of Cairo could have had something to do with his holding on to his position. He was the cousin of the two preceding muhtasibs of Cairo, which is unusual for this period, in which muhtasibs were generally not related to one another; the position clearly was not an inherited one.

32 See Lapidus, "The Grain Economy," 6.

33 Sulük, 2:396.

34 Nelly Hanna, An Urban. History of Bulaq in the Mamluk and Ottoman Periods. As Hanna explains, the port at Fustat remained significant until around 780/1378, when the Red Sea trade route began to bypass Qus for taxation purposes and entered land at Suez or Tur. Goods then traveled overland to the Delta, and arrived in Cairo on boats coming from the north of the city. Hanna, 15-16. According to Hanna, "the new itinerary excluded Mișr and passed via Būlāq instead, hence the decline of one and the rise of the other." Ibid., 16.

${ }^{35}$ Diya $\vec{a}^{\prime}$ al-Din was replaced in Fustat six months after his appointment in Cairo.

${ }^{36}$ Sulük, 2:438.

37 When he was arrested the next year, the people celebrated for three days near the citadel. Sulūk, 2:479-80.

${ }^{38}$ Al-Nashw's ability to force him from office may have been related to the return of chief judge Jalāl al-Din to Syria in $738 / 1337$, because he had been a patron and protector of Diya $\vec{a}$ al-Din.

39 Sulük, 2:758.

40 Ibid., 2:653.

${ }^{41}$ Ibid., 2:772. Al-Maqrīzī reported that prior to that time there had only been a qāẹt 'askar for the Shafíi school.

42 Suluk, 3:232-33.

$4: 3$ Ibid., 3:233.

44 Ibid., 3:233-37.

45 Ibid.

46 Ibid., 3:239.

47 Ibid.

48 Sulūk, 3:799; Ibn al-Furāt, 9:366.

49 Sulük 3:818; Ibn al-Furāt, 9:387.

50 Sulük, 3:818.

51 Ibid.

52 al-Tirmidhī, 1235; Abū Dāwūd, 2974.

53 Petry discusses the biography of al-T ablāwi but states that he was actually appointed muhtasib. Petry, 215. I believe that Ibn al-Burjī remained muhtasib until 797/1395. Sulük, 3:773, 839.

54 Ibn al-Furät, 9:387.

55 Ibid., 9:427.

56 Inbä al-ghumr, 1:507.

57 Ibn al-Furāt, 9:427.

58 Ibn al-Furāt, 9:427-28. Note that the muhtasib of Cairo resigned in 798/1395 but the Sultan also reinstated him less than a month later. Perhaps both muhtasibs were protesting forced sales. 
59 Ibid., 9:428.

60 Ibid., 9:432; Sulük, 3:853-54. This included instructing the same amir alTablāwī to provide bread to the poor in Cairo and Fustat. Ibid., 9:433-34.

61 Ibn al-Furät, 9:434-35.

62 Ibid., 9:435. The port of Bulaq is specifically mentioned-contrast this with the case of the Fustat granaries in which only the Fustat port was involved.

63 Ibn al-Furāt, 9:439; Sulük, 3:859.

${ }^{64}$ Ibn al-Furāt, 9:439.

65 Sulük, 3:859; Ibn al-Furāt, 9:439.

66 Sulük, 3:859; Nuzhat al-nufüs, 1:430, even specifies and says take control of the matter of "hisba," but it is still clear that he was not appointed muhtasib.

67 Ibn al-Furāt, 9:439.

68 Sulūk, 3:860; Ibn al-Furāt, 9:439.

.69 Sulūk, 3:860; Ibn al-Furāt, 9:439-40.

${ }^{70}$ There are several variations of the spelling of his name, but this seems the most common.

71 Sulūk, 3:859-60.

72 Ibn al-Furāt, 9:440.

73 Sulük, 3:996.

\section{BIBLIOGRAPHY}

Cook, Michael, Commanding Right and Forbidding Wrong in Islamic Thought (Cambridge: Cambridge University Press, 2002).

[Fiqh Encyclopedia] Wizārat al-awqāf wa l-shu'ūn al-islāmiyya. Al-Mawsūía al-fiqhiyya, 41 vols. to date (Kuwait 1983-).

Hanna, Nelly, An Urban History of Bulaq in the Mamluk and Ottoman Periods (Cairo: IFAO, 1983).

al-Himyarī, 'Abd al-Razzāq b. Hammām, al-Musannaf (Markaz al-Turāth al-Jāmi' al-Kabīr, CD-ROM).

Ibn al-Furāt, Muhammad b. 'Abd al-Rahịim, Tän̄kh Ibn al-Furāt, vols. 7-9, ed. Qusțanțin Zurayq (Beirut 1936-42).

Ibn al-Sayrafi, Nuzhat al-nufüs wa l-abdān fi tawāīkh al-zamān (Cairo, 1970-94).

Lapidus, Ira M., Muslim Cities in the Later Middle Ages (Cambridge: Cambridge University Press, 1984).

- "The Grain Economy of Mamluk Egypt," Journal of the Economic and Social History of the Orient 12 (1969), 1-15.

Leiter, Brian, "Legal Realism," in The Philosophy of Law: An Encyclopedia, ed. C. B. Gray, 2:720-25 (New York: Garland Publishing, 1999).

al-Maqrīzī, see Sulük.

Ighāthat al-umma bi-kashf al-ghumma, ed. Yāsir Sayyid Șālihīn (Cairo, 1999).

Mawsü at al-hadīth al-shañf (CD-ROM version, 2.1).

Petry, Carl, The Civilian Elite of Cairo in the Later Middle Ages (Princeton: Princeton University Press, 1981).

. Rabbat, Nassar, "Representing the Mamluks in Mamluk Historical Writing," in The Historiography of Islamic Egypt (c. 959-1800), ed. Hugh Kennedy (Leiden: Brill, 2001), 69-75.

Sabra, Adam, Poverty and Charity in Medieval Islam (Cambridge University Press, 2000). 
Shoshan, Boaz, "Grain Riots and the 'Moral Economy': Cairo, 1350-1517," Joumal of Interdisciplinary History 10/3 (Winter 1980), 459-78.

[Sulūk]. al-Maqrīzī, Kitäb al-Sulūk li-ma'infat duwal al-mulūk, 4 vols., eds. Sa'̄id 'Abd al-Fattāḥ and Muhammad Mușțafā Ziyāda (Cairo, 1956-73).

Vogel, Frank E., Islamic Law and Legal System: Studies of Saudi Arabia (Leiden: Brill, 2000). 